\title{
Comparative Study on Population Ecological Distribution and Extracellular Enzyme Activities of Endophytic Fungi in Artemisia annua
}

\section{Zhuangzhuang Liu', Yan Chen'1, Bo Lian'1, Zhen Zhang1, Yanyan Zhao', Zhihao Ji1, Yanna Lv*, Hangao Li ${ }^{2 *}$}

${ }^{1}$ Weifang Medical University, Weifang, China

${ }^{2}$ Affiliated Hospital of Weifang Medical University, Weifang, China

Email: *lynlyna@163.com, *lihangao@hotmail.com

How to cite this paper: Liu, Z.Z., Chen, Y., Lian, B., Zhang, Z., Zhao, Y.Y., Ji, Z.H., Lv, Y.N. and Li, H.G. (2019) Comparative Study on Population Ecological Distribution and Extracellular Enzyme Activities of Endophytic Fungi in Artemisia annua. Journal of Biosciences and Medicines, 7, 94-105. https://doi.org/10.4236/jbm.2019.78008

Received: July 3, 2019

Accepted: August 26, 2019

Published: August 29, 2019

Copyright $\odot 2019$ by author(s) and Scientific Research Publishing Inc. This work is licensed under the Creative Commons Attribution International License (CC BY 4.0). http://creativecommons.org/licenses/by/4.0/

\begin{abstract}
The endophytic fungi in different tissues of Artemisia annua was isolated and purified to explore their ecological distribution and tissue preference, and the extracellular enzyme activities of dominant endophytic fungi were determined to characterize the metabolic function of endophytic fungi. The results showed that a total of 67 endophytic fungi were obtained from Artemisia annua tissues. The number and species of endophytic fungi in different tissues were significantly different. The number, colonization rate (CR) and isolation rate (IR) of endophytic fungi in root were significantly higher than those of stem and leaf. The dominant endophytic fungi, diversity and similarity coefficient of endophytic fungi also showed significant difference among tissues. The extracellular enzyme activities of endophytic fungi in different tissues are significantly different. The enzyme activities of endophytic fungi isolated from root are significantly higher than those isolated from stem and leaf. The research results showed that the endophytic fungi in Artemisia annua had significant tissue preference, and the metabolic function of endophytic fungi showed significant difference among tissues. This will lay a foundation for further research, development and utilization of endophytic fungi, and also provide a theoretical basis for screening functional endophytic fungi in Artemisia annua.
\end{abstract}

\section{Keywords}

Artemisia annua, Endophytic Fungi, Population Structure, Extracellular Enzymes 


\section{Introduction}

Artemisia annua is the traditional Chinese medicine, and it contains volatile oils, artemisinin, flavonoids as well as other various bioactive substances [1]. It has strong adaptability, wide distribution and many effects such as relieving heat and fever [2], also as the source of artemisinin for malaria treatment. Artemisinin has significant effect on the treatment of various types of malaria with little toxic and side effects [3]. Therefore, the research on Artemisia annua gradually became a hotspot for scientists [1] [3].

Research has shown that endophytic fungi widely exist within plant tissues without causing apparent harm to the host [4]. They are rich in species diversity and co-evolve with the host. In this process, endophytic fungi and host formed a reciprocal symbiotic relationship. On the one hand, plants provide photosynthate and minerals for endophytic fungi; on the other hand, metabolites from endophytic fungi can stimulate plant growth and development, also can increase host plants' tolerance to biotic and abiotic stresses [5] [6]. Therefore, endophytic fungi have important ecological significance in the process of plant succession.

In this special evolutionary environment, endophytic fungi can not only produce biological activity secondary metabolites that are identical or similar to those produced by the host [7] [8] [9], but also contribute to the production of traditional Chinese medicine by specific action [10]. Because endophytic fungi are rich in resources and abundant in quantity, they are gradually becoming an important source for screening new bioactive substances [8] [9]. Therefore, studying the endophytic fungi in medicinal plants has potential economic value. Related research shows that the metabolites of endophytic fungi in Artemisia annua stem have the varying degree bacteriostasis function. Among them, some may produce active ingredients which are similar to the active ingredients produced by the host plant [11]. However, the current research on Artemisia annua and its endophytic fungi mostly focus on the extraction and application of medicinal active ingredients and secondary metabolites, there is still no systematic study on the community structure, tissue ecological distribution and metabolic function of endophytic fungi in Artemisia annua.

Studies have shown that the yield and quality of medicinal plants are not only related to the individual growth and system development of plants, but also closely related to their living environment [12]. In this special symbiotic system of "endophytic fungi-medicinal plants" [13], endophytic fungi can release various types of functional extracellular enzymes to invade into plant tissues and complete the catabolic process, and then can survive in this special environment of plant tissues. Therefore, the extracellular enzymes activities of endophytic fungi are the important indicators that can reflect the catabolic function of endophytic fungi [14]. Monitoring extracellular enzymes activities of endophytic fungi has important ecological significance for explaining the symbiosis system of "endophytic fungi-medicinal plants". 
Based on this, we select Artemisia annua with important medicinal value as the research object, and apply the related theories, techniques and methods of plant physiological ecology, microbial ecology and molecular biology to explore the ecological distribution, metabolic functional characteristics and illuminate the tissue preference of endophytic fungi in Artemisia annua. At the same time, a large number of endophytic fungi resources of Artemisia annua were isolated and collected to provide a reliable theoretical basis for the development and utilization of new plant resources and functional enzyme-producing fungi. This study has important practical significance for the sustainable development and ecological safety of Artemisia annua.

\section{Materials and Methods}

\subsection{Sample Collection}

Three sample plots of Artemisia annua were selected in the medicinal plant garden of Weifang Medical University in 2018. Four strains of Artemisia annua were randomly collected in each sample plot and put them into a sterilized sealed polyethylene bag and brought back to the laboratory. These samples were stored in a refrigerator at $4^{\circ} \mathrm{C}$ and isolate endophytic fungi from roots, stems, leaves within $3 \mathrm{~d}$ after collection.

\subsection{Isolation and Purification of Endophytic Fungi}

We used the improved tissue separation to isolate endophytic fungi. Surface sterilization was performed using the modified method [15] [16]. These plant tissues were ground and shredded under aseptic conditions, then were shaken with sterile water for half an hour. The liquid after shaking was diluted to three different gradients and was respectively coated on potato dextrose agar (PDA) supplemented with streptomycin $(50 \mathrm{mg} / \mathrm{L})$, three repetitions per gradient. Then they were cultured at $28^{\circ} \mathrm{C}$ and were observed periodically. After mycelia were developed, they were transferred to new PDA plate. Tissue boiling filtration as medium method: appropriate amount of each plant tissue was boiled with water and use the filtered liquid to configure PDA medium. Then the fungi were isolated and purified according to the traditional tissue separation method [16] [17] [18]. The method can simulate a growth environment which is similar to the plant body to separate more endophytic fungi. PDA medium was used to preserve fungal strains.

\subsection{Analysis of Fungal Community Structure}

Purified endophytic fungi were transferred to PDA plates and were observed after incubation at $28^{\circ} \mathrm{C}$ for 1 week. The species of endophytic fungi were identified according to the traditional morphology. The sporulated strains were identified based on the relative monographs and original descriptions of species [19] [20] [21] [22]. Beyond that, use CTAB method to extract the total fungal genome, and then the total DNA was amplified by using fungal (18S rDNA, 
FR1-GC and FF390) universal primers. The PCR reaction system and the amplification reaction procedure referred to the methods of Vainio and Hantula (2000) and Heuer et al. (1999). Then the DNA amplification products were analyzed using Denaturing Gel Gradient Electrophoresis [23]. DNA was sequenced using high-throughput sequencing technology which was completed by Huada Genomics Institute and the obtained rDNA sequences of fungi were clustered and analyzed in Gen Bank.

\subsection{Determination of Extracellular Enzyme Activities of Endophytic Fungi}

The extracellular enzyme activities were determined using degradation substrate-colorimetric method to characterize the enzyme-producing function of endophytic fungi. Firstly, the purified strains were cultured at $25^{\circ} \mathrm{C}$ for $3 \mathrm{~d}$, and then pour sterile water into them. Scraped the hyphae and transferred them to a fermentation medium (potato $200 \mathrm{~g} / \mathrm{L}$, starch $20 \mathrm{~g} / \mathrm{L}$, corn flour $5 \mathrm{~g} / \mathrm{L}, \mathrm{KH}_{2} \mathrm{PO}_{4} 3$ $\mathrm{g} / \mathrm{L}, \mathrm{MgSO}_{4} \cdot 7 \mathrm{H}_{2} \mathrm{O} 1.5 \mathrm{~g} / \mathrm{L}, \mathrm{V}_{\mathrm{B}} 110 \mathrm{mg} / \mathrm{L}$, trace element mixture $7 \mathrm{~mL} / \mathrm{L}$ ) for shaking culture for $4 \mathrm{~d}$ at $25^{\circ} \mathrm{C}, 150 \mathrm{r} / \mathrm{min}$. Take the upper culture solution to centrifuge at $5000 \mathrm{r} / \mathrm{min}$ at $4^{\circ} \mathrm{C}$ for $10 \mathrm{~min}$. The supernatant is acted as crude enzyme solution to determinate cellulose (E.C.3.2.1.4) [24], polyphenol oxidase (PPO; E.C.1.10.3.1) [25], acid phosphatase (ACP; E.C.3.1.3.2) [26] and laccase activity (E.C.1.10.3.2) [27].

\subsection{Statistical Analysis Method}

Colonization rate (CR) was calculated as the total number of segments incubated divided by the total number of plant tissue segments infected by fungi [28], which could compare the degrees infected by endophytic fungi between different plant tissues. Calculation formula: $\mathrm{CR}=$ (number of sample blocks infected by endophytic fungi/number of total tissue blocks) $\times 100 \%$.

Isolation rate (IR) was determined as the total number of segments incubated divided by the number of endophytic fungi isolated from plant segments. IR could measure fungal richness in a given sample of plant tissues and the incidence of multiple infections per plant segments [29]. Calculation formula: IR = (number of designated type of strain isolated from tissue blocks/number of total tissue blocks) $\times 100 \%$.

The Shannon-Weaver biodiversity index $H$ was calculated according to the formula: $H=-\sum_{i=1}^{k} P i+\ln P i$, where $k$ is the total number of certain fungal species, and $P i$ is the percentage of the number of a certain strain to the total number of endophytic fungi [30].

Sorenson's similarity coefficient $\left(C_{\mathrm{S}}\right)$ was employed and calculated according to the following Formula [31]: $C_{\mathrm{S}}=2 j /(\mathrm{a}+\mathrm{b})$, where $j$ is the number of co-existing fungal species in two plant tissues, $a$ is the number of fungal species in one plant tissue, and $b$ is the number of fungal species in the other plant tissue. 


\section{Results and Analysis}

\subsection{Colonization Rate and Isolation Rate of Endophytic Fungi}

A total of 67 endophytic fungi were obtained from Artemisia annua, of which 29strains were isolated from roots, 10 strains were isolated from stems, and 28 strains were isolated from leaves. They respectively accounted for $43.3 \%, 14.9 \%$ and $41.8 \%$ of the total fungi (Table 1). The degree of infection by endophytic fungi in the different tissues is different. The root was most infected by endophytic fungi, and the CR reaches $70 \%$. The second was the leaf and CR reaches $62.5 \%$. The tissue with the lowest infection degree was the stem, and the CR was $37.5 \%$ (Table 1).

The frequency of multiple infestation from endophytic fungi in each tissue is significantly different, and the highest was the root organization, with a maximum IR of $72.5 \%$. The lowest was the stem, with a separation rate of $25 \%$ (Table 1).

\subsection{Population Structure of Endophytic Fungi}

On the taxonomic level of genus, these 67 endophytic fungi were divided into 16 taxa (Table 1). Fusarium sp. and Humicola sp. are the dominant species, respectively were 18 and 10 strains. They respectively accounted for $26.86 \%$ and $14.42 \%$ of the total fungi (Table 2).

Endophytic fungi isolated from root tissue was divided into 10 genera. Fusarium $s p$. was the most abundant species and there were 11 strains, accounting for $16.41 \%$ of the total fungi isolated from root. Therefore, Fusarium sp. was the dominant strain in the root tissue. The number of endophytic fungi in the stem accounts for a small proportion, and they were divided into 10 genera. Phoma $s p$.was the dominant strain of the stem, accounting for $50 \%$ of the total fungi isolated from stem (Table 1). In the leaf tissue, the number of endophytic fungi was large, and they were divided into 10 genera. Humicola $s p$. was the dominant population in leaves and accounted for $35.7 \%$ of the total fungi isolated from leaf (Table 2).

\subsection{Diversity and Similarity Coefficient of Endophytic Fungi}

The diversity and similarity coefficients of endophytic fungi in the three tissues

Table 1. Colonization rate and isolation rate of endophytic fungi of Artemisia annua.

\begin{tabular}{cccccc}
\hline Item & Root & Stem & Leaf & Total & Average \\
\hline Number of inoculated tissue blocks & 40 & 40 & 40 & 120 & 40 \\
Number of infected tissue blocks & 28 & 15 & 25 & 68 & 22.7 \\
Number of isolated strains & 29 & 10 & 28 & 67 & 22.3 \\
$\quad \begin{array}{c}\text { Colonization rate (\%) } \\
\text { Isolation rate (\%) }\end{array}$ & 70 & 37.5 & 62.5 & 170 & 56.7 \\
$\begin{array}{c}\text { Proportion of isolated strains to } \\
\text { total strains }\end{array}$ & 72.5 & 25 & 70 & 167.5 & 55.8 \\
\end{tabular}


Table 2. Population distribution of endophytic fungi in Artemisia annua.

\begin{tabular}{|c|c|c|c|c|c|}
\hline Endophytic fungi & $\begin{array}{l}\text { Quantity in } \\
\text { root/strain }\end{array}$ & $\begin{array}{l}\text { Quantity in } \\
\text { stem/strain }\end{array}$ & $\begin{array}{l}\text { Quantity in } \\
\text { leaf/strain }\end{array}$ & Total/strain & $\begin{array}{l}\text { Proportion of } \\
\text { total strains (\%) }\end{array}$ \\
\hline Papularia sp. & & & 3 & 3 & 4.47 \\
\hline Alternaria sp. & 5 & 1 & 2 & 8 & 11.94 \\
\hline Penicillium sp. & 1 & & & 1 & 1.49 \\
\hline Aspergillus sp. & & & 1 & 1 & 1.49 \\
\hline Humicola sp. & & & 10 & 10 & 14.42 \\
\hline Cylindrocaipon sp. & 1 & & & 1 & 1.49 \\
\hline Fusarium sp. & 11 & 2 & 5 & 18 & 26.86 \\
\hline Nigrospora sp. & & & 1 & 1 & 1.49 \\
\hline Endophragmiella sp. & 1 & & & 1 & 1.49 \\
\hline Rhizopus sp. & & & 1 & 1 & 1.49 \\
\hline Phoma sp. & & 5 & & 5 & 7.46 \\
\hline Chaetonium sp. & 4 & & 1 & 5 & 7.46 \\
\hline Pestalotiopsis sp. & 2 & & 3 & 5 & 7.46 \\
\hline Setodochium sp. & 2 & 1 & & 3 & 4.47 \\
\hline Rhizoctonia sp. & 1 & & 1 & 2 & 2.98 \\
\hline Cladosporium sp. & 1 & 1 & & 2 & 2.98 \\
\hline Total & 29 & 10 & 28 & 67 & 100 \\
\hline
\end{tabular}

were significantly different. The coefficient of root is the highest (1.53), the coefficient of stem is the lowest (0.56), and the coefficient of leaf (1.38) is between the root coefficient and the stem coefficient (Figure 1). The diversity coefficients of root and leaf are significantly higher than that of stem. The similarity coefficient of root and stem was the highest (0.57), followed by the similarity coefficient of root and leave (0.48), and the lowest was the similarity coefficient of stem and leave (0.25) (Figure 2). This indicates that the endophytic fungi species in root and stem tissues were most similar, followed by root and leave, and the endophytic fungi of stem and leave had the largest difference in species composition.

\subsection{Extracellular Enzyme Activities of Dominant Endophytic Fungi of Artemisia annua}

A total of four dominant endophytic fungi were isolated from Artemisia annua tissues. Fusarium $s p$. come from root tissue, Phoma $s p$. come from stem tissue, Humicola $s p$. and Fusarium $s p$. come from leaf tissue. On the whole, extracellular enzyme activities of dominant endophytic fungi from root and stem were significantly higher than those from leaf (Figure 3). Cellulase mainly acts on cellulose and participates in the carbon metabolism of plants. Cellulase activities of Fusarium sp. and Phoma sp. were significantly higher than those of Humicola $s p$. and Alternaria $s p$. Cellulase activity of Humicola $s p$. had the weakest activity and the activity was $0.06 \mathrm{IU}$ (Figure 3 ). Laccase is mainly to catalyze the oxidative polymerization of substrates. The main activity in Artemisia annua is to catalyze the oxidative decomposition of lignin. The laccase activity of Phoma sp. 


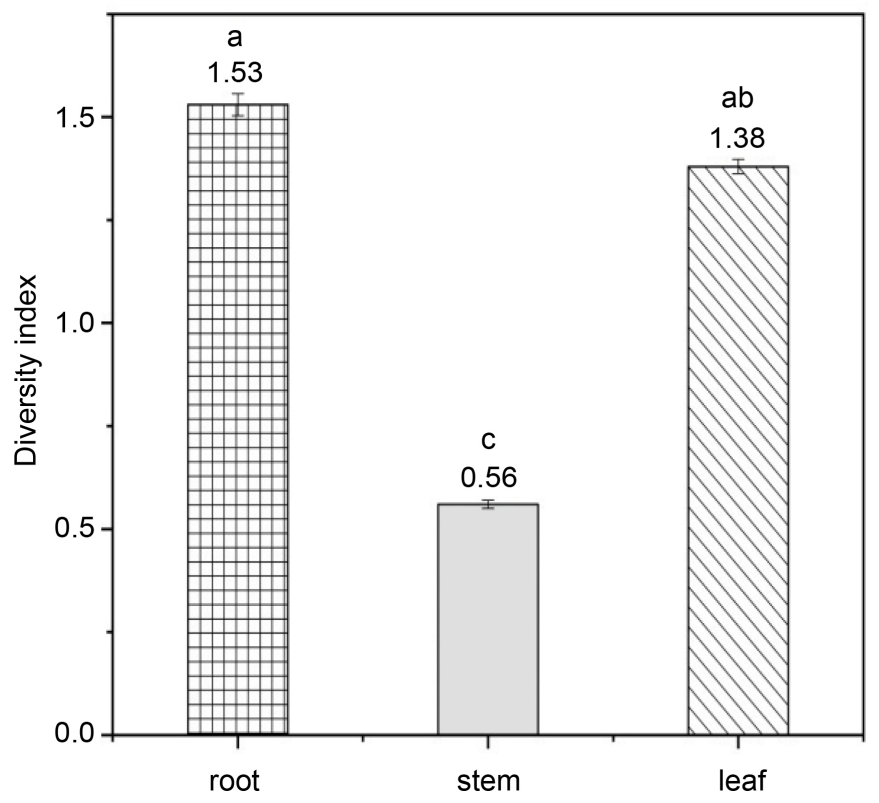

Figure 1. The diversity coefficient of endophytic fungi.

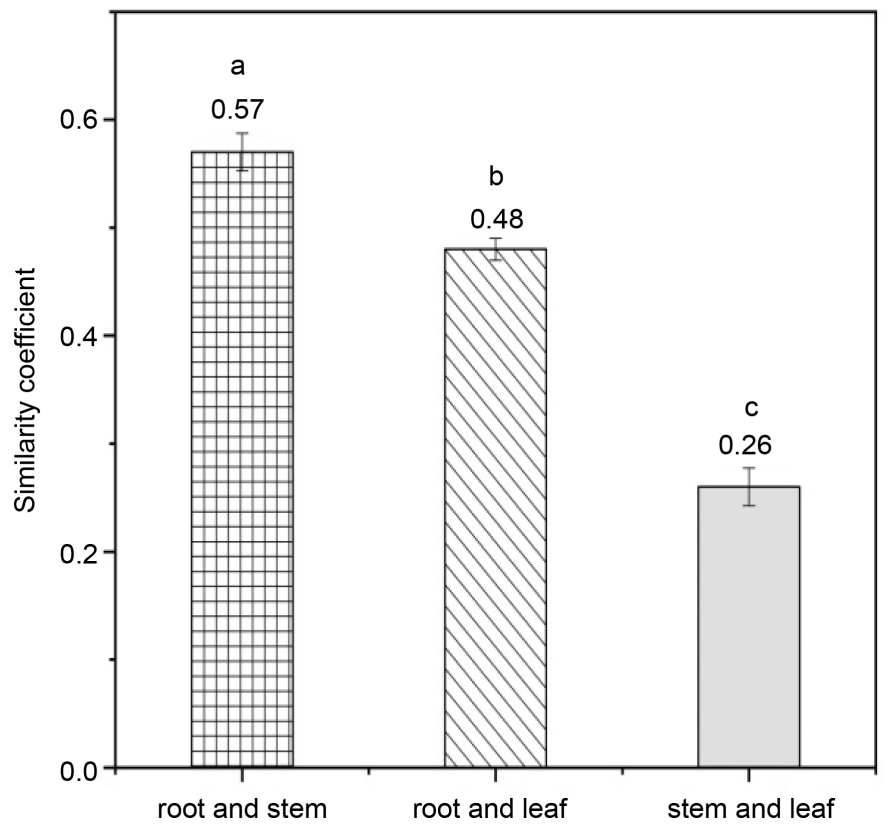

Figure 2. The similarity coefficient of endophytic fungi

was the strongest with $10.63 \mathrm{IU}$, and the laccase activity of Humicola $s p$. was the weakest (Figure 3). The main role of polyphenol oxidase is to promote the oxidation of polyphenols to quinonoids. The polyphenol oxidase activities of Phoma $s p$. and Fusarium sp. were significantly stronger than those of other strains, respectively with an activity of $1.73 \mathrm{IU}$ and $1.67 \mathrm{IU}$. The polyphenol oxidase activity of Humicola sp. was the weakest. ACP activity involved P cycling of Fusarium $s p$. was significantly stronger than that of other strains. ACP activities of Phoma sp. and Humicola sp. were lower (Figure 3). 

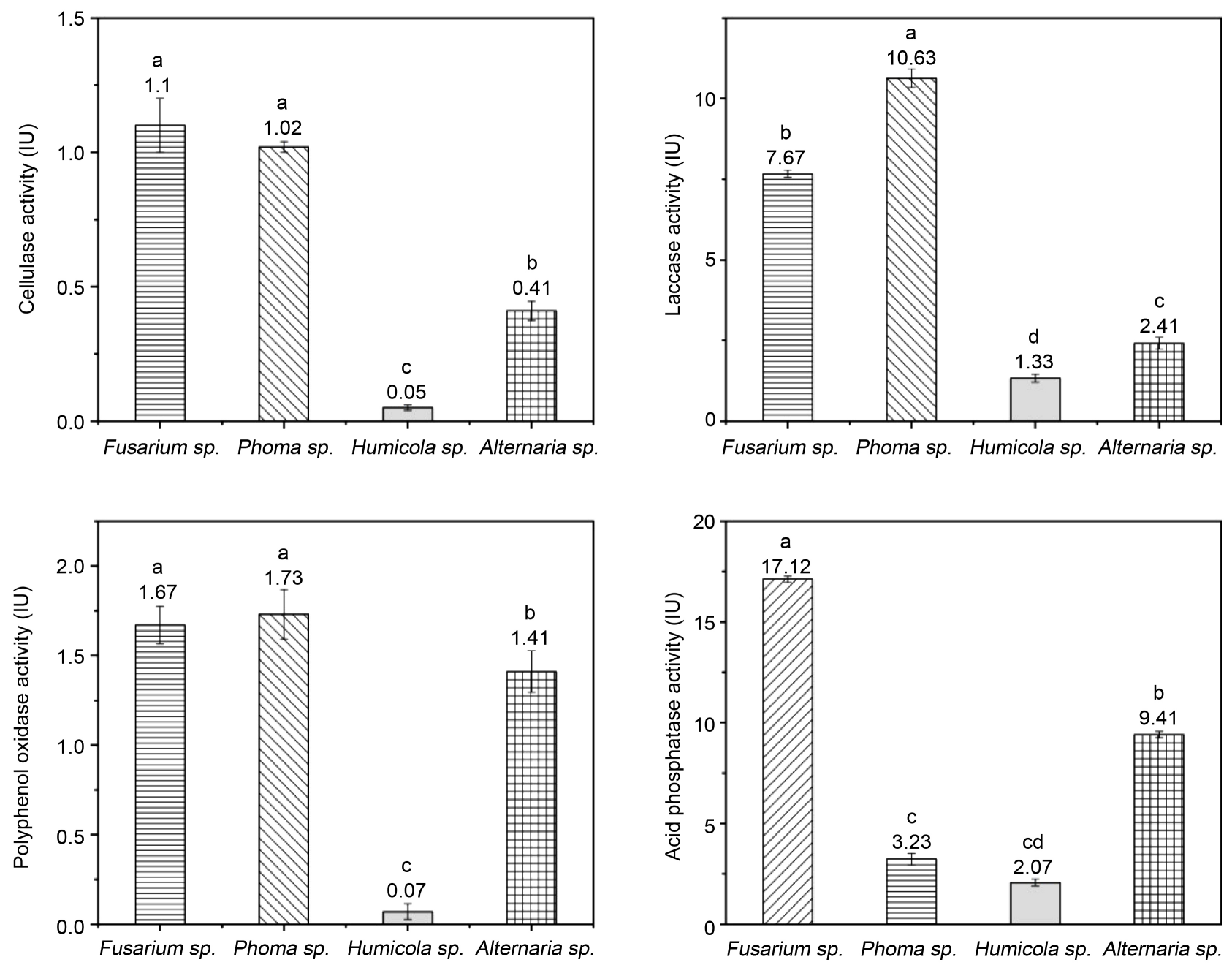

Figure 3. Extracellular enzyme activities of dominant endophytic fungi of Artemisia annua.

\section{Discussion}

From the distribution of endophytic fungi isolated from different tissues of $\mathrm{Ar}$ temisia annua, Cephalosporium sp. was distributed in different tissues, and the number was large, indicating that Cephalosporium $s p$. was a dominant population in Artemisia annua plants. The differences in population distribution and population size of endophytic fungi in different tissues of Artemisia annua were significant. Host cells and endophytic fungi had certain tissue specificity and particularity [29]. This may be caused by the influence of plant environment and also may because of the differences of the microenvironments among the tissues, such as the differences of organizational preference, enzymes and other factors. Similar results on the ecological distribution of endophytes in roots, stems, and barks of Azadirachta indica A. Juss by Verma et al. (2007) showed that the maximum species richness of endophytes appeared in the leaf segments rather than the stem and bark tissues, whereas the bark samples showed the maximum diversity.

The results showed that the roots, stems and leaves of Artemisia annua had 
high endophytic colonization rate $(37.5 \%-75.0 \%)$, which was similar to some previous studies. For example, Barengo et al. pointed out that the endophytic fungal colonization rate of the roots of Phyllostachys pubescens could reach $63.4 \%$ [32]. Collado et al. pointed out that the colonization rate of endophytic fungi in Quercus ilex was 55.4\%, and that of the endogenous fungus Portuguese oak was $64.6 \%$ [33]. In this study, it was also found that the colonization rate of endophytic fungi in roots of Artemisia annua was significantly higher than that in stems. In the study from Collado et al. (2000), the colonization rate of endophytic fungi in holly and Portuguese eucalyptus roots reached $76.3 \%$ and $81.9 \%$ respectively, and another study also reported similar conclusions [34] [35] [36]. This difference may be caused by differences in the structure and nutrients contained in the plant tissue.

The study results showed that the roots contained more endophytic fungi than stems and leaves and population distribution is significantly different in these three organizations. This indicated that endophytic fungi had certain preferences at the plant tissue level. This may be because the structure and nutrients in different plant tissues are not identical, and the nutrients requirements of different endophytic fungi were not identical, which affected the colonization, infection, growth and distribution of endophytic fungi [37].

Detection of extracellular enzyme activity of dominant endophytic fungi can characterize its metabolic function, and then reveal the growth state of medicinal plants and the symbiotic relationship between "endophytic fungi-medicinal plants" from the perspective of endophytic fungi. The results showed that the extracellular enzyme activities of dominant endophytic fungi were significantly different in different tissues [38]. In general, the extracellular enzyme activities of endophytic fungi in roots and stems were higher than those in leaves. This indicates that the metabolism of endophytic fungi in roots and stems is more vigorous, which may be related to the internal environment of plant tissues and self-properties of endophytic fungi [7].

Through in-depth study on the community structure and extracellular enzymes of endophytic fungi in medicinal plants, we can grasp the distribution characteristics of endophytic fungi in host plants, and obtain a large number of endophytic fungi resources. This will lay a foundation for further research, development and utilization of endophytic fungi. Studies on endophytic fungi in plants in recent decades have shown that endophytic fungi could synthesize the same or similar active constituents to the host plants [8]. Therefore, the active substances of endophytic fungi can be screened and be applied to the market. It is possible to solve the problem of insufficient drug supply in China, and also provide a theoretical basis for screening functional endophytic fungi endophytic fungi as a production strain [39] [40].

\section{Conclusion}

The endophytic fungi in different tissues of Artemisia annua was isolated and 
purified, and the extracellular enzyme activities of dominant endophytic fungi were determined. A total of 67 endophytic fungi were obtained from Artemisia annua tissues. The number and species of endophytic fungi in different tissues were significantly different. The dominant endophytic fungi, diversity and similarity coefficient of endophytic fungi also showed significant difference among tissues. The enzyme activities of endophytic fungi isolated from root are significantly higher than those isolated from stem and leaf. The research results showed that the endophytic fungi in Artemisia annua had significant tissue preference, and the metabolic function of endophytic fungi showed significant difference among tissues. This will provide a theoretical basis for further research, development and utilization of endophytic fungi.

\section{Acknowledgements}

This study was supported by National Natural Science Foundation of China (31600386) and Natural Science Foundation of Shandong Province (ZR2015CL014).

\section{Conflicts of Interest}

The authors declare no conflicts of interest regarding the publication of this paper.

\section{References}

[1] Wang, L, Dai, Y.X., Fan, X.L., et al. (2015) Effects of Wind on Hydraulic Properties and Growth of Artemisia annua Linn. Acta Ecologica Sinica, 35, 4454-4461. https://doi.org/10.5846/stxb201410071963

[2] Zhang, H. and Zhang, N. (2007) Determination of Artemisinin in Artemisia annua L. from Varieces Sources by Ultrasonic Extraction and UV-Spectrophotometry. Chinese Journal of Pharmaceutical Analysis, 27, 414-416.

[3] Tonk, S., Bartarya, R., Maharaj, K.K., et al. (2006) Effective Method for Extraction of Larvicidal Component from Leaves of Azadirachta indica and Artemisia annua Linn. Journal of Environmental Biology, 27, 103-105.

[4] Petrini, O. (1991) Fungal Endophytes of Tree Leaves. In: Andrews, J.H. and Hirano, S.S., Eds., Microbial Ecology of Leaves, Springer-Verlag, New York, 179-197. https://doi.org/10.1007/978-1-4612-3168-4_9

[5] Senthilmurugan, G., Vi, J. and Eyini, M. (2013) Endophytic Fungi of the Climber Epipremnum aureum (L) Engl and Its Symbiotic Association with Their Host Tree, Annona squamosa L. International Journal of Agronomy \& Plant Production, 4, 3645-3650.

[6] Mei, Y.X. and Xing, G.S. (2000) Establishment of Symbiotic System for Anoectochilus roxburghii (Wall.) Lindl. and Endophytic Fungi. China Journal of Chinese Materia Medica, 25, 81.

[7] Chen, H.Q., Xu, Y.P., Xie, L.H., Wang, G.H. and Yang, M.H. (2006) Isolation of Endophytic Fungi in Tea Plant (Camellia sinensis) and Their Distribution Patterns in Different Tissues. Journal of Laiyang Agricultural College, 4, 250-254.

[8] Zhao, J., Shan, T., Mou, Y., et al. (2011) Plant-Derived Bioactive Compounds Produced by Endophytic Fungi. Mini-Reviews in Medicinal Chemistry, 11, 159-168. 
https://doi.org/10.2174/138955711794519492

[9] Kaul, S., Gupta, S., Ahmed, M., et al. (2012) Endophytic Fungi from Medicinal Plants: A Treasure Hunt for Bioactive Metabolites. Phytochemistry Reviews, 11, 487-505. https://doi.org/10.1007/s11101-012-9260-6

[10] Siciliano, S.D. (2001) Selection of Specific Endophytic Bacterial Genotypes by Plants in Response to Soil Contamination. Applied and Environmental Microbiology, 67, 2469-2475. https://doi.org/10.1128/AEM.67.6.2469-2475.2001

[11] Zhu, F., Lin, Y.C., Wang, J., Zhou, S.N. and Vrijmoed, L.P. (2005) Metabolites of Amangrove Endophytic Fungus Stysanus like sp. Fromthe South China Sea. Chemical Research and Application, 17, 790-792.

[12] Lin, J.F., Liu, M.Z. and Chen, X.Y. (2009) Evaluation of Assay Methods for Determining Fungal Laccase Activity. Chinese Journal of Bioprocess Engineering, 7, 1-8.

[13] Huang, W.Y., Cai, Y.Z., Xing, J., et al. (2007) A Potential Antioxidant Resource: Endophytic Fungi from Medicinal Plants. Economic Botany, 61, 14-30. https://doi.org/10.1663/0013-0001(2007)61[14:APAREF]2.0.CO;2

[14] Yang, S., Chao, D.C., Ling, L.U., et al. (2002) Comparison of the Extracellular Enzyme Activities of Theendophytic Fungi in Four Species of Medicinal Plants from Euphorbiaceae. Journal of Plant Resources and Environment, 11, 17-20.

[15] Guo, L.D., Hyde, K.D. and Liew, E.C.Y. (2000) Identification of Endophytic Fungifrom Livistona chinensis Based on Morphology and rDNA Sequences. New Phytologist, 147, 617-630. https://doi.org/10.1046/j.1469-8137.2000.00716.x

[16] Wang, Y., Guo, L.D. and Hyde, K.D. (2005) Taxonomic Placement of Sterile Morphotypes of Endophytic Fungi from Pinus tabulaeformis (Pinaceae) in Northeast China Based on rDNA Sequences. Fungal Diversity, 20, 235-260.

[17] Guo, L.D., Hyde, K.D. and Liew, E.C.Y. (1998) A Method to Promote Sporulation in Palm Endophytic Fungi. Fungal Diversity, 1, 109-113.

[18] Guo, L.-D. (2001) Advances of Researches on Endophytic Fungi. Mycosystema, 20, 148-152.

[19] Sutton, B.C. (1980) The Coelomycetes: Fungi Imperfecti with Pycnidia Acervuli and Stromata. Commonwealth Mycological Institute, Kew, 1-696.

[20] Barnett, H.L. and Hunter, B.B. (1998) Illustrated Genera of Imperfect Fungi. 4th Edition, APS Press, St. Paul, 1-218.

[21] Heitefuss, R. (2012) The Genera of Hyphomycetes. Journal of Phytopathology, 160, 166. https://doi.org/10.1111/j.1439-0434.2011.01872.x

[22] Ellis, M.B. (1977) More Dematiaceous Hyphomycetes. Mycologia, 69, 439. https://doi.org/10.2307/3758674

[23] Kowalchuk, G.A., Buma, D.S., Boer, W.D., et al. (2002) Effects of Above-Ground Plant Species Composition and Diversity on the Diversity of Soil-Borne Microorganisms. Antonie van Leeuwenhoek, 81, 509. https://doi.org/10.1023/A:1020565523615

[24] Qing, Q. and Wyman, C.E. (2011) Supplementation with Xylanase and $\hat{\mathrm{I}}^{2}$-xylosidase to Reduce Xylo-Oligomer and Xylan Inhibition of Enzymatic Hydrolysis of Cellulose and Pretreated Corn Stover. Biotechnology for Biofuels, 4, 18. https://doi.org/10.1186/1754-6834-4-18

[25] Demir, Y. and Kocacaliskan, I. (2001) Effects of $\mathrm{NaCl}$ and Proline on Polyphenol Oxidase Activity in Bean Seedlings. Biologia Plantarum, 44, 607-609. https://doi.org/10.1023/A:1013715425310

[26] Ghose, T.K. (1987) Measurement of Cellulase Activity. Pure and Applied Chemi- 
stry, 59, 257-268. https://doi.org/10.1351/pac198759020257

[27] Lai, C.F., et al. (2010) Progress of Applications of Laccase in Organic Synthesis. Chemical Industry and Engineering Progress, 7, 1300-1308.

[28] Mishra, A. and Kumar, S. (2007) Cyanobacterial Biomass as N-Supplement to Agro-Waste for Hyper-Production of Laccase from Pleurotus ostreatus in Solid State Fermentation. Process Biochemistry, 42, 681-685. https://doi.org/10.1016/j.procbio.2006.09.022

[29] Pielou, E.C. (1975) Ecological Diversity. John Wiley and Sons Inc., New York, 165.

[30] Shi, W., Luo, J.P., Ding, Z.H. and Wu, J. (2005) Isolation and Identification of Endophytic Fungi of Huperzia serrata. Chinese Traditional and Herbal Drugs, 36, 281-283.

[31] Petrini, O., Stone, J.K. and Carroll, F.E. (1982) Endophytic Fungi in Evergreen Shrubs in Western Oregon: A Preliminary Study. Canadian Journal of Botany, 60, 789-796. https://doi.org/10.1139/b82-102

[32] Barengo, N., Sieber, T.N. and Holdenrieder, O. (2000) Diversity of Endophytic Mycobiota in Leaves and Twigs of Pubescent Birch (Betula pubescens). Sydowia, 52, 305-320.

[33] Collado, J., Platas, G. and Peláez, F. (2000) Host Specificity in Fungal Endophytic Populations of Quercus ilex and Quercus faginea from Central Spain. Nova Hedwigia, 71, 421-430.

[34] Ahlich, K. and Sieber, T.N. (1996) The Profusion of Dark Septate Endophytic Fungi in Non-Ectomycorrhizal Fine Roots of Forest Trees and Shrubs. New Phytologistogist, 132, 259-270. https://doi.org/10.1111/j.1469-8137.1996.tb01845.x

[35] Ananda, K. and Sridhar, K.R. (2002) Diversity of Endophytic Fungi in the Roots of Mangrove Species on the West Coast of India. Canadian Journal of Microbiology, 48, 871-878. https://doi.org/10.1139/w02-080

[36] Tan, X.M., Chen, X.M., Wang, C.L., et al. (2012) Isolation and Identification of Endophytic Fungi in Roots of Nine Holcoglossum Plants (Orchidaceae) Collected from Yunnan, Guangxi, and Hainan Provinces of China. Current Microbiology, 64, 140-147. https://doi.org/10.1007/s00284-011-0045-8

[37] Kaneko, R. and Kaneko, S. (2004) The Effect of Bagging Branches on Levels of Endophytic Fungal Infection in Japanese Beech Leaves. Forest Pathology, 34, 65-78. https://doi.org/10.1111/j.1439-0329.2004.00350.x

[38] Pruidze, G.N., Mchedlishvili, N.I., Omiadze, N.T., et al. (2003) Multiple Forms of Phenol Oxidase from Kolkhida Tea Leaves (Camellia sinensis L.) and Mycelia Sterilia IBR 35219/2 and Their Role in Tea Production . Food Research International, 36, 587-595. https://doi.org/10.1016/S0963-9969(03)00006-1

[39] Zhou, X., Zhu, H., Liu, L., et al. (2010) A Review: Recent Advances and Future Prospects of Taxol-Producing Endophytic Fungi. Applied Microbiology and Biotechnology, 86, 1707-1717. https://doi.org/10.1007/s00253-010-2546-y

[40] Zhu, D., Wang, J., Zeng, Q., et al. (2010) A Novel Endophytic Huperzine A Producing Fungus, Shiraia sp. Slf14, Isolated from Huperzia serrata. Journal of Applied Microbiology, 109, 1469-1478. https://doi.org/10.1111/j.1365-2672.2010.04777.x 